16 a 18 de autubro de 2019 - Campinas | Brasil

\title{
Transumanismo e racionalidade neoliberal
}

\author{
Maria Cornelia Crucean*, Andrei Koerner
}

\section{Resumo}

O presente trabalho teve como foco a análise sistemática do movimento transumanista, suas bases teóricas, objetivos e estratégias de ação, assim como as críticas levantadas ao movimento e suas relações com a ordem político-econômica neoliberal.

\section{Palavras-chave: \\ Neoliberalismo, Governamentalidade, Transumanismo}

\section{Introdução}

O transumanismo defende o aprimoramento do ser humano e de suas capacidades intelectuais, físicas e psicológicas por meio das tecnociências. O movimento tende a expressar ideologias polícas individualistas e libertárias e se articula à racionalidade governamental neoliberal ao se centrar no aperfeiçoamento e na eficiência do indivíduo no contexto da concorrência permanente específica desse sistema. Nos últimos anos, o movimento alcançou a esfera da política por meio da criação de partidos políticos transumanistas para promover a tecnologia como força geradora das mudanças sociais. Assim, o projeto teve como objetivos:

1. Objetivo geral: analisar sistematicamente 0 movimento transumanista e entender seus objetivos e estratégias de ação.

\section{Objetivos específicos:}

a) compreender a base teórica do movimento;

b) analisar comparativamente os vários tipos de correntes transumanistas em termos de suas bases doutrinárias, objetivos e estratégias e ação;

c) entender e clasificar as críticas levantadas a este movimento;

d) elaborar uma análise sistemática das relações entre transumanismo e neoliberalismo.

\section{Resultados e Discussão}

Ao se alinhar à governamentalidade neoliberal, o transumanismo aspira ampliar o espaço da decisão humana, presumindo que a liberação da agência humana é a condição da auto-realização e do bem-estar e que o exercício dessa agência está centrado no indivíduo. Mais do que isso, o transumanismo convida os indivíduos a capitalizarem suas capacidades físicas e mentais para perseguir autonomamente seu próprio caminho da autorealização e os pressiona a aumentar essas capacidades para melhorar sua eficiência neste processo. O movimento entende o livre mercado como a estrutura adequada para alcançar essa liberação e para explorar plenamente o potencial dos indivíduos. ${ }^{1}$

O rápido desenvolvimento das ciências convergentes (NBIC) oferece um certo grau de credibilidade às visões de transcendência e transformação próprias do movimento transumanista. $\mathrm{O}$ nível de apoio institucional deve ser reconhecido, já que essas tecnologias são apoiadas por programas de pesquisa bem financiados, enquanto as corporações e os Estados competem ferozmente por elas. A área militar está igualmente interessada em certas aplicações dessas tecnologias. ${ }^{2}$
Porém, nessa onda de evolução tecnológica, surgem algumas inquietações em relação à possível discriminação genética, à lacuna entre a informação, a previsão genética e as terapias disponíveis, e o potencial aumento de uma nova forma de eugenia baseada na junção de informação e abuso dos dados. Os direitos humanos também estão colocados em questão pela nova forma como o movimento transumanista entende a dignidade humana, no sentido de que essa poderia ser de diferentes graus por meio da aplicação das tecnologias de aperfeiçoamento. A crítica feita é que isso poderia minar os direitos humanos e que a aplicação das tecnologias de aprimoramento revelaria um caminho para a padronização e eficiência, típico da racionalidade governamental neoliberal.

\section{Conclusões}

Fica evidente a necessidade das reflexões críticas acerca dos efeitos produzidos pela articulação das mudanças tecnológicas à governamentalidade neoliberal sobre os direitos humanos. $O$ acesso às tecnologias provavelmente será limitado, pois dependeria, principalmente, dos meios financeiros dos indivíduos. Os benefícios podem não ser amplamente compartilhados, contribuindo para o aumento das desigualdades sociais. As intervenções de aperfeiçoamento humano também podem introduzir distinções entre aquelas pessoas aprimoradas e aquelas que não tiveram acesso às tecnologias, havendo o risco de violação de princípios fundamentais dos direitos humanos como, por exemplo, os de não-discriminação e não-estigmatização. $O$ uso das tecnologias de aprimoramento remove a ideia de unicidade de cada indivíduo e introduz a noção de que alguns atributos do corpo humano e da individualidade podem ser substituídos. Esta possibilidade minaria o que é único em cada indivíduo e promoveria a padronização de certos atributos humanos, sejam eles físicos, mentais ou estéticos, de acordo com as demandas do mercado.

\section{Agradecimentos}

Meus agradecimentos vão para o Prof. Dr. Andrei Koerner que foi um grande mentor para mim nesse anos em que participei em projetos de pesquisa com o apoio dele.

\footnotetext{
${ }^{1}$ ARNALDI, Simone. The End of History and the Search for Perfection: Conflicting Teleologies of Transhumanism and (Neo)liberal Democracy. In: PELLIZZONI, Luigi; YLÖNEN, Marja (Ed.). Neoliberalism and Technoscience: Critical Assessments. Surrey, UK: Ashgate Publishing Limited, 2012, p. 93-116.
}

${ }^{2}$ LILLEY, Stephen. Transhumanism and Society: The Social Debate Over Human Enhancement. Springer Science \& Business Media, 2012. 